\title{
The Extent of Engaging Public School Teachers in Amman in the Decision Making Process from their Perspective
}

\author{
Yaser Jadee Suleiman Al Mahthi
}

\begin{abstract}
The present research aimed to explore the extent of engaging public school teachers in Amman in the decision making process from their perspective. To be specific, it aimed to explore the engagement of those teachers in making decision related to teachers, students, curricula and local community. A purposive sample was selected involving 450 female and male teachers. Those teacher were chosen from 25 public primary schools and 25 public secondary schools in Amman. Questionnaire form were passed to the chosen teachers by hand. They were fully retrieved. However, 2 forms were excluded due to having items that aren't answered. Thus, the final sample consists from 448 female and male teachers. SPSS software was used. It was found that the extent of engaging public school teachers in Amman in the decision making process is low in all the area jointly. The extent of engaging public school teachers in making local community-related decisions is moderate. The extent of engaging public school teachers in making decisions related to teachers, students and curricula is low. The researcher recommends developing plans by the Ministry of Education in Jordan to ensure that teachers are highly involved in the decision making process.
\end{abstract}

Keywords: engagement, public schools, teachers, Amman, decision making, perspective

DOI: $10.7176 / \mathrm{JEP} / 11-30-13$

Publication date:October $31^{\text {st }} 2020$

\section{Introduction:}

Decentralization has been receiving much attention in business and political fields due to its major benefits. From a political perspective, it may be defined as the transmission of powers related to making decision and planning and allocating resources from the central government to subordinate units. In business organizations, it's represented in delegating powers by managers to subordinates. It can be adopted in educational institutions, such as schools. Decentralization in school context, it is represented in the transmission of powers related to making decision and planning and allocating resources by the principal to teachers (Hussein, 2006). To be more specific, it involves engaging teachers in the decision making process. It shall empower teachers and enable them to understand the way plans are set and decisions are made. It shall improve the quality of school services. It shall make the school management responsive to community needs. It promotes democracy in school (Zajda \& Gamage, 2009)

However, adopting a decentralized approach in schools requires meeting several requirements. Such requirements include knowledge-related requirements. For instance, administrators in schools must have much knowledge about the significance adopting a decentralized approach. Other requirements include: human-related requirements. For instance, there must be qualified well-trained staff capable of addressing any problem that might face the school or hinder the adopting of this approach. Other requirements include: legislative requirements. For instance, the relevant regulations must allow the school staff to adopt this approach. Other requirements include: the financial requirements. To illustrate more, schools must be provided with the need financial support for adopting this approach (Hallaq, 2012).

Through adopting a decentralized approach in schools, the teachers shall be involved in the decision making process. The latter process can be defined as a cognitive and affective interaction between one and the members of a group in order to make decisions, utilize potentials \& efforts, meet the intended goals and handle responsibilities (Al-Anzi, 2006). It can be defined as a goal oriented process that aims to determine the problem and suggest solutions for addressing it with incurring the least possible cost, dedicating the least effort and showing the highest efficiency level (Al-Arabi, 2014).

It should be noted that several governments develop strategies for increasing the extent of engaging teachers in the decision making process. Such strategies are developed to achieve reform in the educational field (Smylie, 1992). . According to Al-Sofyani (2012) and Barakat (2015), teachers should be involved in making decisions related to teachers, students, curricula and local community. According to Smylie (1992), teachers should be engaged in making decisions related to curriculum, instruction, personnel, staff development and administrative matters (Smylie, 1992)

Engaging teachers in the decision making process has many benefits. For instance, it shall lead to making an effective decisions due to taking various views into consideration. It shall make the teachers feel motivated to implement the decisions that were made. It shall promote acceptance for the decisions among the teachers (Najm, 2012). It shall enable the school management to handle problems and difficult situations (Al-Arabi, 2014). It shall increase the teachers' compliance with the school policies. That is because teachers participated in the process of 
developing such policies (Smylie \& Tuermer, 1992)

Engaging teachers in the decision making process shall enable decision makers in schools to perceive any problem from various perspectives. It shall enable the decision makers in schools to pay attention to all the aspects of any problem. In fact, no one is capable of paying attention to all the aspects of a specific problem by himself/herself without consulting others (Al-Shaqsi, 2005). Such engagement shall provide teachers with opportunities to express their views and opinions. It shall provide teachers with opportunities to make suggestions for improving their work conditions and facilitating their communication with the principal. It shall provide principals with support and assistance that facilitate the processes of doing tasks by them. It shall make teachers feel that they serve as valuable resources in the schools they work at (Al-Sofyani, 2012)

Engaging teachers in the decision making process shall create a convenient workplace environment. It promotes acceptance among teachers for change (Al-Sofyani, 2012). Such engagement shall promote trust between the principal and the teachers (Herz Allah, 2007). Due to the significance of such engagement, the researcher of the present study believes that it's necessary to shed a light on the reality of such engagement, especially in developing countries. That is because there is a high need for developing the educational systems in such countries. Thus, the researcher aimed to investigate the extent of engaging public school teachers in Amman in the decision making process from their perspective.

\section{Objective:}

This study aimed to investigate the extent of engaging public school teachers in Amman in the decision making process from their perspective.

\section{Question:}

This study aimed to answer the question mentioned below:

What is the extent of engaging public school teachers in Amman in the decision making process from their perspective?

\section{Significance}

The present study is significant because:

It provides plan developers in the Ministry of Education in Jordan with information that can be used for developing effective plans for empowering teachers and engaging them in the process of making school-related decisions.

It contributes to promoting awareness about the significance of having teachers engaged in the process of making school-related decisions.

It promotes awareness among officials in the Ministry of Education in Jordan about the significance of providing principals with courses about the engagement of teachers in the process of making school-related decisions

\section{Limits}

The present study was conducted during the first semester of the academic year (2020/2021) in 25 public primary schools and 25 public secondary schools in Amman.

\section{Definition of Terms:}

-Decision making process (theatrical definition): It is a goal oriented process that aims to determine the problem and suggest solutions for addressing it with incurring the least possible cost, dedicating the least effort and showing the highest efficiently (Al-Arabi, 2014).

-Decision making process (empirical definition): It refers to the decision making process that is carried out in public schools in Amman.

\section{Theatrical framework}

Engaging teachers in the decision making process shall improve the teachers' morale and increase their satisfaction with their jobs. It shall positively affect the teachers' performance and improve the quality of the provided education. That is because such engagement shall make teachers feel that their views are significant and valuable at the workplace. (Al-Fa'oori, 2004). Such engagement shall lead to allocating responsibilities and tasks to several teachers and administrators instead of allocating them to one of them. Thus, it shall lead to reduce the work load of each teacher (Al-Shaqsi, 2005).

Engaging teachers in the decision making process shall contribute to providing schools with human resources who are highly qualified. That is because the teachers shall be involved in the process of choosing the training courses that meet their needs. It's because the teachers shall be involved in the process of choosing the incentives that encourage them to develop themselves professionally (Al-Anzi, 2006). Such engagement shall positively 
affect the students' academic achievement and the organizational performance of the school. That is because such engagement shall lead to making decisions that take the students' needs and interests into consideration (Wadesango, 2012)

Such engagement shall positively affect the teachers' motivation to work. That is because they shall feel that their views are given attention and considered significant. Such engagement shall improve their decision making skills. It shall promote creativity and a sense of initiative among teachers. That is because teachers shall compete with each other to propose the most creative ideas while making the decision. Such engagement shall positively affect the partnership and relationship between teachers and principals (Bayaga and Wadesango, 2013)

Such engagement shall lead to promoting trust and harmony among teachers and principals. That is because such engagement shall positively the teachers' feelings towards the principal and loyalty to the school they work at. Such engagement shall positively affect the long-term planning in the school and the quality of the decisions made by the school principal. That is because such engagement shall enable principals to benefit from the expertise that teachers have (Bayaga and Wadesango, 2013)

Such engagement shall improve the school's performance effectiveness and efficiency and the productivity of teachers in the school. It improves the ability of the school management to respond rapidly to changes and problems. It improves the ability of the school management to seize the available opportunities. It shall provide the school management with various alternatives. That is because such engagement shall provide the school management with various views. Such engagement shall improve the school outcomes. That is because such engagement shall enable the school management to make the right decision on the right time (Bayaga and Wadesango, 2013). Such engagement shall make the workplace environment at school a friendly one due to having harmony among principal and teachers (Bayaga and Wadesango, 2013). It shall reduce the teachers' feelings of stress (Wadesango, 2017).

\section{Empirical studies}

Al-Sofyani (2012) aimed to explore the degree to which secondary school teachers are engaged in the decision making process in Taif, Saudi Arabia. To be specific, he aimed to explore that in terms of the decisions related to students, teachers, curricula, local community, financial issues \& school facilities. He adopted a descriptive analytical approach. He used a questionnaire. A stratified random sample was chosen. It consists from 380 teachers. Questionnaire forms are distributed to them. 360 form are retrieved and 354 ones of those are valid for analysis. Several results were concluded. For instance, the degree to which secondary school teachers are engaged in the decision making process is low in all the areas jointly. The extent of engaging those teachers in making studentsrelated decisions is moderate. The extent of engaging those teachers in making decisions related to teachers, curricula, local community, financial issues or school facilities is low

Barakat et al. (2015) aimed to explore the degree to which school teachers are engaged in the decision making process in Lattakia, Syria. They adopted a descriptive approach and employed a survey. The sample consists from 371 female and male teachers. The latter scholars found that the degree to which teachers are engaged in the process of making decisions related to students, teachers, curricula, local community, financial issues and school building is high. There are significant differences between the teachers' extent of engagement in the decision making process which can be attributed to experience and academic qualifications.

Sarafidou and Chatziioannidis (2013) aimed to explore the degree to which primary school teachers are engaged in the decision making process in Greece. They used a questionnaire for obtaining data from 143 teachers. Those teachers were chosen from several primary schools located in different areas in Greece. The latter scholars found that primary school teachers in Greece are highly engaged in the process of making decisions related to students and teachers. The extent of engaging those teachers in the process of making administrative decisions is low. The extent of engaging teachers in the decision making process affects the job satisfaction and self-efficacy levels of teachers.

Mosheti (2013) aimed to explore the degree to which teachers are engaged in the decision making process in Botswana. 221 teachers were sampled. A survey was employed for data collection. SPSS software was employed. Several findings were reached. For instance, teachers are highly engaged in the process of making decisions related to guiding students to achieve academic progress and make future career choices. Teachers aren't highly engaged in making decisions related to school budget, governance, and staff. Such engagement shall improve the teachers' satisfaction and commitment.

Alghamdi (2020) aimed to explore the degree to which teachers are engaged in the decision making process in Riyadh. He aimed to explore whether there is a significant relationship between the level of such engagement and the principal's leadership style. He selected a random sample that consists from 325 teachers. A descriptive approach was adopted to conduct the study. They used a questionnaire. They employed the SPSS software for having the needed data collected. The latter scholar found that the degree to which teachers are engaged in the decision making process in Riyadh is high. He also found that there is a negative relationship between authoritarian leadership and such engagement. However, a positive relationship exists between such engagement and social 
leadership.

Hollyns (2017) aimed to explore the degree to which the public secondary school teachers are engaged in the decision making process in Delta State, Nigeria. He aimed to explore the impact of such engagement on teachers' morale and job satisfaction. Data was collected from 976 public secondary school teachers. It was found that such engagement level is low. There is a positive significant relationship between teachers' morale and job satisfaction from one hand and their engagement in the decision making process from another hand.

Olorunsola and Olayemi (2011) aimed to explore the extent of secondary school teachers' engagement in the decision making process in Ekiti, Nigeria. 200 teachers were sampled. The latter scholars used a questionnaire. ANOVA, t-test, and Scheffe post hoc test were conducted. Percentages and frequencies were conducted. The random sampling technique was employed by the latter scholars. Several results were concluded. For instance, the extent of secondary school teachers' engagement in the decision making process in Ekiti, Nigeria is high. Teachers' suggestions are taken into consideration when taking decisions in vital issues at school. Teachers are involved in setting plans for developing the welfare of the staff. They are involved in determining the measures of disciplining students. There are significant differences between the teachers' extent of engagement in this process which can be attributed to experience. Those differences are for the favour of the ones who have 30-35 years.

\section{Methodology}

\subsection{Approach}

The descriptive analytical approach was adopted

\subsection{Population and Sample}

The population involves all the public school teachers in Amman. A purposive sample was selected involving 450 female and male teachers. Those teacher were chosen from 25 public primary schools and 25 public secondary schools in Amman. Questionnaire form were passed to the chosen teachers by hand. They were fully retrieved. However, 2 forms were excluded due to having items that aren't answered. Thus, the final sample consists from 448 female and male teachers. Data about the sample is shown below

Table (1): Data about the sample

\begin{tabular}{|l|l|l|l|}
\hline Variable & Category & Frequency & Percentage \\
\hline \multirow{2}{*}{ Gender } & Male & 209 & 46.65 \\
\cline { 2 - 4 } & Female & 239 & 53.34 \\
\hline \multirow{2}{*}{ Type of school } & Primary public school & 245 & 54.68 \\
\cline { 2 - 4 } & Secondary public school & 203 & 45.31 \\
\hline
\end{tabular}

$\mathrm{N}=448$

$46.65 \%$ of the teachers are males and $53.34 \%$ of the teachers are females. $54.68 \%$ of the teachers work in public primary schools and $45.31 \%$ of the teachers work in public secondary schools.

\subsection{Instrument}

The researcher developed a questionnaire based on the studies conducted by Al-Sofyani (2012) and Barakat (2015). The questionnaire in this study consists from four sections. Through those sections, the researcher aims to explore the extent of engaging public school teachers in Amman in the process of making decisions related to (students, teachers, curricula and local community). The cover sheet of this questionnaire confirms that data shall treated as confidential data. It confirms that no one can have access to the collected data

\subsection{Validity of the Instrument}

The initial version of the questionnaire was passed to two instructors who work at a Jordanian university and specialized in the field of educational leadership. Those instructors are $\mathrm{PhD}$ holders and have much knowledge and expertise in the latter field. They were asked to make an evaluation for the study. They added that the questionnaire is very clear and relevant to the goal of the study. They added that there isn't any need for making any change to the questionnaire. The questionnaire was passed to the teachers and those two instructors in Arabic language. Then, it was translated into English.

\subsection{Reliability of the Instrument}

The Cronbach alpha values are calculated for each area. They are shown below: 
Table (2): Cronbach alpha values

\begin{tabular}{|l|l|l|}
\hline No. & Area & Cronbach alpha \\
\hline 1. & Engagement in the process of making decisions related to students & 0.89 \\
\hline 2. & Engagement in the process of making decisions related to teachers & 0.82 \\
\hline 3. & Engagement in the process of making decisions related to curricula & 0.85 \\
\hline 4. & Engagement in the process of making decisions related to local community & 0.80 \\
\hline & Overall & 0.84 \\
\hline
\end{tabular}

All those values indicate that the questionnaire is reliable, because they are greater than 0.70 as it's suggested by Salehi \& Farhang (2019).

\subsection{Statistical analysis:}

To analyse the obtained data, the researcher used SPSS program and calculated standard deviations along with means. He calculated frequencies and percentages. He calculated Cronbach alpha coefficient. The criteria employed for having the means classified are shown below:

Table (3): The criteria that are used by the researcher for classifying means

\begin{tabular}{|l|l|l|}
\hline Range & Level & Attitude \\
\hline 2.33 or less & Low & Negative \\
\hline $2.34-3.66$ & Moderate & Neutral \\
\hline 3.67 or more & High & Positive \\
\hline
\end{tabular}

*Source: Al-Amery (2020)

Regarding the five point Likert scale, it consists from five (5) rating categories that are shown below.

Table (4): The categories and scores of the five point Likert scale

\begin{tabular}{|l|l|l|l|l|l|}
\hline Category & Always & Often & Sometimes & Rarely & Never \\
\hline The score it represents & 5 & 4 & 3 & 2 & 1 \\
\hline
\end{tabular}

\section{Discussion and Results:}

What is the extent of engaging public school teachers in Amman in the decision making process from their perspective?

To have this question answered, the researcher calculated the mean of each area. He also calculated the overall mean for all the study's areas jointly. Those means are shown through table (5)

Table (5): The mean of each area of the study's areas

\begin{tabular}{|l|l|l|l|l|l|}
\hline No. & Area & Mean & Std. & Level & Rank \\
\hline 1. & Engagement in the process of making decisions related to students & 2.18 & 0.34 & Low & 3 \\
\hline 2. & Engagement in the process of making decisions related to teachers & 2.24 & 0.40 & Low & 2 \\
\hline 3. & Engagement in the process of making decisions related to curricula & 2.07 & 0.49 & Low & 4 \\
\hline 4. & $\begin{array}{l}\text { Engagement in the process of making decisions related to local } \\
\text { community }\end{array}$ & 2.64 & 0.33 & Moderate & 1 \\
\hline & Overall & 2.28 & 0.39 & Low & \\
\hline
\end{tabular}

Based on table (5), the overall mean is 2.28 which is low. That means that the extent of engaging public school teachers in Amman in the decision making process is low from the perspective of those teachers. That indicates that public school principals in Amman don't have much awareness about the significance of engaging teachers in the decision making process.

The mean of the extent of engaging teachers in decisions related to local community is 2.64 which is moderate and ranked first. The mean of the extent of engaging teachers in the decisions related to teachers is 2.24 , which is low and ranked second. The mean of the extent of engaging teachers in decisions related to students is 2.18 which is low and ranked third. The mean of the extent of engaging teachers in decisions related to curricula is 2.07 which is low and ranked fourth.

Results about each area are presented below:

\subsection{Engagement in the process of making decisions related to students}

Table (6): Means and standard deviations for investigating the extent of engaging public school teachers in Amman in the process of making decisions related to students

\begin{tabular}{|l|l|l|l|l|l|}
\hline No. & Statement & Mean & Std. & Level & Rank \\
\hline 1. & $\begin{array}{l}\text { I participate in the process of determining which competitions to be } \\
\text { held }\end{array}$ & 1.31 & 0.63 & Low & 4 \\
\hline 2. & $\begin{array}{l}\text { I propose solutions for addressing the problem of having students } \\
\text { coming late to class }\end{array}$ & 4.69 & 0.18 & High & 1 \\
\hline
\end{tabular}




\begin{tabular}{|l|l|l|l|l|l|}
\hline No. & Statement & Mean & Std. & Level & Rank \\
\hline 3. & $\begin{array}{l}\text { I participate in the process of setting plans for motivating students and } \\
\text { raising their academic achievement }\end{array}$ & 3.39 & 0.52 & Moderate & 2 \\
\hline 4. & $\begin{array}{l}\text { I participate in the process of choosing the students who shall } \\
\text { participate in competitions }\end{array}$ & 1.18 & 0.34 & Low & 5 \\
\hline 5. & $\begin{array}{l}\text { I propose solutions for addressing the problem of having students } \\
\text { running from school }\end{array}$ & 1.07 & 0.27 & Low & 6 \\
\hline 6. & $\begin{array}{l}\text { I participate in the process of developing schedules for the school trips } \\
\text { and entertainment activities }\end{array}$ & 1.49 & 0.15 & Low & 3 \\
\hline & Overall & 2.18 & 0.34 & Low & \\
\hline
\end{tabular}

*Source: Al-Sofyani (2012)

Based on the table above, extent of engaging public school teachers in Amman in the process of making decisions related to students is low due to having a mean of 2.18. This mean is low. This result is consistent with the result concluded by Al-Sofyani (2012). Despite that, teachers are the ones who interact the most with students in the school. Thus, they have much knowledge about the students' needs, demands, weaknesses and strengths. That makes teachers capable of making students-related decisions of high quality.

Statement (2) states the following: (I propose solutions for addressing the problem of having students coming late to class). The mean of statement (2) is 4.69 which is deemed high and ranked first. It indicates that principals realize that teachers know the things that can motivate student to come early to school and know the punishments that can't be used to achieve this goal.

Statement (5) states the following: (I propose solutions for addressing the problem of having students running from school). The mean of statement (5) is 1.07 which is deemed low and ranked last. It may be attributed to the belief of principals that this problem requires involving parents and social workers rather than teachers.

\subsection{Engagement in the process of making decisions related to teachers}

Table (7): Means and standard deviations for investigating the extent of engaging public school teachers in Amman in the process of making decisions related to teachers

\begin{tabular}{|l|l|l|l|l|l|}
\hline No. & Statement & Mean & Std. & Level & Rank \\
\hline 1. & I participate in the process of setting the time schedule of exams & 3.98 & 0.61 & High & 1 \\
\hline 2. & $\begin{array}{l}\text { I participate in the process of determining the training courses that I } \\
\text { shall attend }\end{array}$ & 2.15 & 0.42 & Low & 3 \\
\hline 3. & $\begin{array}{l}\text { I add issues to the meeting agenda of the teachers-principal meeting in } \\
\text { order to hold discussions about such issues }\end{array}$ & 2.53 & 0.27 & Moderate & 2 \\
\hline 4. & $\begin{array}{l}\text { I assist the principal in setting the schedule that identify which teacher } \\
\text { shall attend the classes on behalf of the absent teacher }\end{array}$ & 1.67 & 0.38 & Low & 5 \\
\hline 5. & $\begin{array}{l}\text { I participate in the process of distributing tasks to teachers at the } \\
\text { beginning of the semester (e.g. supervisory tasks) }\end{array}$ & 1.29 & 0.59 & Low & 6 \\
\hline 6. & $\begin{array}{l}\text { I participate in the process of determining the time on which the } \\
\text { teachers shall hold a meeting }\end{array}$ & 1.84 & 0.15 & Low & 4 \\
\hline & Total & 2.24 & 0.40 & Low & \\
\hline
\end{tabular}

*Source: Al-Sofyani (2012)

The extent of engaging public school teachers in Amman in the process of making decisions related to teachers is low due to having a mean that is 2.24. This result is consistent with the result concluded by Al-Sofyani (2012). Such low engagement shall lead to making decisions that aren't for the favour of teachers. It may lead to providing teachers with courses that don't meet their training needs. It may lead to making decision that aren't consistent with the teachers' needs, skills, and capabilities.

Statement (1) states the following: (I participate in the process of setting the time schedule of exams). The mean of statement (1) is 3.98. It's deemed high and ranked first. It indicates that principals realize that teachers should be engaged in the process of setting the time schedule of exams. That is because teachers are able to determine the dates of exams in a manner that fits with the implementation of the academic plans.

Statement (5) states the following: (I participate in the process of distributing tasks to teachers at the beginning of the semester (e.g. supervisory tasks). The mean of statement (1) is 1.29. It's deemed low and ranked last. Such low participation shall negatively affect the teachers' performance in doing tasks. That is because teachers have knowledge about the skills of their colleagues and the tasks that can be done efficiently be their colleagues. 


\subsection{Engagement in the process of making decisions related to curricula}

Table (8): Means and standard deviations for investigating the extent of engaging public school teachers in Amman in the process of making decisions related to curricula

\begin{tabular}{|l|l|l|l|l|l|}
\hline No. & Statement & Mean & Std. & Level & Rank \\
\hline 1. & I suggest methods for assessing the content of curricula & 1.35 & 0.17 & Low & 5 \\
\hline 2. & I suggest methods for meeting the goals of curricula & 2.35 & 0.26 & Moderate & 3 \\
\hline 3. & $\begin{array}{l}\text { I make suggestions about the resources that should be added to the } \\
\text { school library }\end{array}$ & 2.54 & 0.83 & Moderate & 2 \\
\hline 4. & $\begin{array}{l}\text { I develop plans for ensuring that the content of the curricula fits with } \\
\text { real life }\end{array}$ & 1.19 & 0.52 & Low & 6 \\
\hline 5. & I develop programs for improving the creativity and talents of students & 1.16 & 0.34 & Low & 7 \\
\hline 6. & $\begin{array}{l}\text { I assist the principal in addressing the problems related to the content } \\
\text { of the curricula }\end{array}$ & 2.20 & 0.75 & Moderate & 4 \\
\hline 7. & I make plans for carrying out co-curricular activities & 3.72 & 0.59 & High & 1 \\
\hline & Overall & 2.07 & 0.49 & Low & \\
\hline
\end{tabular}

*Source: Al-Sofyani (2012) and Barakat (2015)

The extent of engaging public school teachers in Amman in the process of making decisions related to curricula is low due to having a mean that is 2.07. This mean is low. This result is inconsistent with the result included by Barakat (2015). It indicates that principals aren't aware of the significance of the role of teachers in improving curricula and addressing the weaknesses of curricula.

Statement (7) states the following: (I make plans for carrying out co-curricular activities). The mean of this statement is 3.72 which is ranked first and deemed high. It indicates that the sampled teachers are highly aware about the significance of carrying out co-curricular activities. For instance, such activities contribute to developing students' thinking skills and providing them with knowledge.

Statement (4) states the following: (I develop programs for improving the creativity and talents of students). The mean of this statement is 1.19 which is low and ranked last. It indicates that principals don't encourage teachers to develop such programs. However, teachers are capable of developing such programs, because they know the needs and desires of the talented and creative students they teach.

\subsection{Engagement in the process of making decisions related to local community}

Table (9): Means and standard deviations for investigating the extent of engaging public school teachers in Amman in the process of making decisions related to local community

\begin{tabular}{|l|l|l|l|l|l|}
\hline No. & Statement & Mean & Std. & Level & Rank \\
\hline 1. & $\begin{array}{l}\text { I participate in the process of planning visits for institutions in the local } \\
\text { community }\end{array}$ & 1.82 & 0.20 & Low & 5 \\
\hline 2. & $\begin{array}{l}\text { I am involved in the planning process that aims at providing support } \\
\text { for poor people in the local community }\end{array}$ & 3.39 & 0.46 & Moderate & 3 \\
\hline 3. & $\begin{array}{l}\text { I make suggestions for increasing the collaboration between the school } \\
\text { and the institutions in the local community }\end{array}$ & 1.27 & 0.58 & Low & 6 \\
\hline 4. & $\begin{array}{l}\text { I convince parents about the significance of attending the parents- } \\
\text { teachers meetings }\end{array}$ & 3.81 & 0.29 & High & 1 \\
\hline 5. & $\begin{array}{l}\text { I participate in the process of solving the problems faced by students } \\
\text { in collaboration with parents }\end{array}$ & 3.69 & 0.17 & High & 2 \\
\hline 6. & $\begin{array}{l}\text { I participate in the process of solving the problems related to the local } \\
\text { community in collaboration with the parents, school administration } \\
\text { and teachers }\end{array}$ & 1.86 & 0.30 & Low & 4 \\
\hline & Overall & 2.64 & 0.33 & Moderate & \\
\hline
\end{tabular}

*Source: Al-Sofyani (2012) and Barakat (2015)

The extent of engaging public school teachers in Amman in the process of making decisions related to local community is moderate due to having a mean that is 2.64 . This result is inconsistent with the result concluded by Al-Sofyani (2012). It indicates that public school principals in Amman don't have much awareness about the significance of the teachers' role in making reforms in the local community. However, teachers play a significant role in making such reforms. For instance, they can encourage students to assist poor and disabled people in the local community. They can make initiatives that encourage students to protect the environment in their country.

Statement (4) states the following: (I convince parents about the significance of attending the parents-teachers meetings). The mean of statement (4) is 3.81 which is deemed high and ranked first. It indicates that the sampled teachers are highly aware about the significance of having the parents attending such meetings. For instance, through such meetings, the teachers can inform the parents about the academic and social problems that the 
students suffer from.

Statement (3) states the following: (I make suggestions for increasing the collaboration between the school and the institutions in the local community). The mean of statement (3) is 1.27 which is deemed low and ranked last. It may be attributed to the lack of awareness among principals about the significance of creating partnerships with institutions in the local community. For instance, creating partnerships with institutions that aim at fighting violence shall contribute to promoting awareness among students about the way of fighting against violence.

\section{Conclusion}

The researcher found that the extent of engaging public school teachers in Amman in the decision making process is low in all the areas jointly. That indicates that public school principals in Amman don't have much awareness about the significance of engaging teachers in the decision making process. It was found the extent of engaging those teachers in making local community-related decisions is moderate. The extent of engaging those teachers in making decisions related to teachers, students and curricula is low.

The results of this study indicate that public school principals in Amman don't realize the positive impacts of such engagement on students, teachers, curricula, the school, and local community. For instance, such engagement contributes to motivating students and promoting creativity among them. It plays a significant role in developing teachers professionally and meeting their training needs. It plays a significant role in addressing the weaknesses of curricula and making reforms in the local community.

\section{Recommendations:}

The researcher recommends:

a) Conducting studies about the impact of the teachers' demographic variables (e.g. gender, age and academic qualifications) on the extent of engaging teachers in the decision making process.

b) Forming several committees in each school and assigning a specific function to each committee. Such committee must be consisting from teachers only. Such committees should by formed by the principal. To illustrate more, there should be a committee responsible for addressing the problems faced by the school and making suggestions for addressing them. There should be another committee responsible for addressing the social problems faced by students. There should be another committee responsible for fostering the collaboration between the school and the institutions in the local community.

c) Developing plans by the Ministry of Education in Jordan to ensure that teachers are highly involved in the decision making process.

d) Providing principals with training courses about the significance of engaging teachers in the decision making process

\section{Acknowledgment:}

The researcher would like to thank the Jordanian Ministry of Education for exerting effort to empower teachers and develop them professionally

\section{References Published in English Language}

Al-Amery, A. (2020). Attitudes of the students at the institutes of fine arts in Iraq towards implementing active learning strategies in Arabic language courses and the associated challenges. Journal of Education and Practice, 11(13), 73-81

Bayaga, A.; and Wadesango, N. (2013). Management of schools: Teachers' involvement in decision making processes. African Journal of Business Management. 7(17), pp. 1689-1694,

Hollyns, B. (2017). Levels of Participation in Decision Making as Correlates of Job Satisfaction and Morale of Teachers in Public Senior Secondary Schools in Delta State. Global Journal of Management and Business Research: Administration and Management, 17(1), 82-96

Mosheti, P. (2013). Teacher Participation in School Decision-Making and Job Satisfaction as Correlates of Organizational Commitment in Senior Schools in Botswana. Published MA thesis. Andrews University. United States

Olorunsola, E.; and Olayemi, A. (2011). Teachers participation in decision making process in secondary schools in Ekiti State, Nigeria. International Journal of Education Administration and Policy Studies. 3(6). 78-84

Salehi, M., \& Farhang, A. (2019). On the adequacy of the experimental approach to construct validation: the case of advertising literacy. Heliyon, 5(5). Retrieved from: https://doi.org/10.1016/j.heliyon.2019.e01686

Sarafidou, J. and Chatziioannidis, G. (2013), Teacher participation in decision making and its impact on school and teachers. International Journal of Educational Management. 27(2), pp. 170-183. https://doi.org/10.1108/09513541311297586

Smylie, M. \& Tuermer, U. (1992). Hammond, Indiana: The politics of involvement v. the politics of confrontation. Claremont, CA: Claremont Graduate School, Claremont Project VISION. 
Smylie, M. (1992). Teacher Participation in School Decision Making: Assessing Willingness to Participate. Educational Evaluation and Policy Analysis. 14(1), 53-67

Wadesango, N. (2012). The Influence of Teacher Participation in Decision-making on Student Performance. The Anthropologist. 14(5).pp. 425-431

Wadesango, N. (2017) . The Influence of Teacher Participation in Decision-making on Their Occupational Morale. Journal of Social Sciences. 31(3). 361-369, https://doi.org/10.1080/09718923.2012.11893046

Zajda, J., \& Gamage, D. T. (2009). Decentralisation and school-based management and quality. In J. Zajda \& D. T. Gamage (Eds.), Decentralisation, school-based management, and quality (pp. xv-xxv). New York: Springer. http://dx.doi.org/10.1007/978-90-481-2703-0

\section{References Published in Arabic Language:}

Al-Anzi, M. (2014). Degree of Practicing the Leadership Styles According to the Managerial Grid Theory by Educational Supervisors from Teachers' Point of View in the State of Kuwait. Published MA thesis. Al Al-Bait University. Mafraq: Jordan. Retrieved from: http://thesis.mandumah.com/Record/302079/Details

Al-Arabi, B. (2014). Engagement in the decision making and human relationships are the pillars of effective communication in the institutions. The Journal of Human and Social Sciences. 6(16), p.167-180. Retrieved from: http://search.shamaa.org/FullRecord?ID=107894

Al-Fa'oori, A. (2004). The impact of organizational silence on collaboration in making organizational decisions in Mu'tah University: A case study. Mu'tah University for Research and Studies in Human and Social Sciences. 19(2)

Alghamdi, S. (2020). Teachers' participation in school decision-making and its relationship to the leadership style of the school leader. Journal of Educational and Psychological Sciences. 4(28), p.53 - 75

Al-Shaqsi, H. (2005). Employees participation in decision making and it's effect on their performance in Sultan Qabous University. Published MA thesis. Al Al-Bait University. Mafraq. Jordan. Retrieved from: http://thesis.mandumah.com/Record/172704

Al-Sofyani, M. (2012). The degree of teachers participation in schools decision-making :field study from the viewpoint of secondary school teachers in Taif Governorat. Published MA Thesis. Um Al-Qurrah University. Saudi Arabia

Barakat, G.; Sbeirh, F. and Tfaha, E. (2015). The Extent of Teachers' Participation in School Decision-Making Process and its Relationship with Some Variables: A Field Study on Teachers of Basic Education in the Province of Lattakia. Tishreen University Journal for Research and Scientific Studies - Arts and Humanities Series, 37(2), 283-305

Hallaq, M. (2012). The requirements of adopting a decentralized approach in primary and secondary public school in the Syrian Arab Republic (A field study in Rif-Dimashq). The Journal of Damascus University. 28(2).155-196 Herz Allah, A. (2007). The extent of engaging secondary school teachers in the decision making process and its relationship with their job satisfaction. Published MA thesis. The Islamic University-Gaza, Gaza: Palestine. http://thesis.mandumah.com/Record/153229/Details

Hussein, S. (2006). Self-management and decentralization in educational institutions. Alexandria. Egypt: Dar Alwafa, ISBN: 9773275922

Najm, N. (2012). The impact of organizational characteristics on organizational loyalty. Ustath Journal for Human and Social Sciences-Baghdad University, 1(203). 